\title{
Student Errors in Completing Mathematical Story Problems Based on Watson's Criteria During Pandemic COVID-19
}

\author{
Malim Muhammad \\ \{malim.muhammad@gmail.com\} \\ Department of Mathematics Education, Faculty of Teacher Training \\ and Education, Universitas Muhammadiyah Purwokerto
}

\begin{abstract}
This study aims to describe students' mistakes in solving story problems based on the Watson Criteria. The material used in this study is a two-variable linear equation system and was implemented at SMP Negeri 1 Kembaran. This type of research is a qualitative description. The subjects of this study were students of 7 th grade class who were selected through purposive sampling technique. Students are grouped into three groups, namely groups of students with high, medium, and low learning achievement. Three students were selected from the three groups. Data collection techniques using written tests and interviews. The data validation test used technical triangulation by comparing the results of written tests and interviews. The results showed that 1) high learning achievement students made mistakes in the response level conflict stage, missing conclusions, missing data, and indirect manipulation; 2) student learning achievement is making mistakes at the stage of the problem of skill hierarchy, response level conflict, missing conclusions, missing data, and indirect manipulation; and 3) students with low learning achievement made mistakes at the stage of incorrect data, skill hierarchy problems, inappropriate procedures, response level conflicts, missing conclusions, missing data, and indirect manipulation.
\end{abstract}

Keywords: Student Errors, Watson's Criteria, Mathematical Story Problems, COVID-19

\section{Introduction}

The learning process in schools is the best effort to increase knowledge and skills. In addition, many students think that school is a very fun activity, they can interact with each other. Schools can improve students' social skills and social class awareness. But now the activity called school has stopped suddenly because of the Covid-19 interference. For Indonesian families is a big surprise especially for the productivity of parents who are usually busy with work outside the home. Likewise with the psychological problems of the children of students who are accustomed to face-to-face learning with their teachers. Mathematics has a big role in everyday life, it can be seen that when learning mathematics, someone will learn to plan, decide, and anticipate problems that come [1]. In solving mathemaical story problems, cognitive skills, understanding of symbols, and understanding of sentences are needed [2]. Mastery of students' math skills needs to be analyzed [3]. It aims to determine the extent to which students understand the material given. Mathematical story problems related to everyday life [4]. Mathematical story problems are a problem that can help students apply mathematical concepts in everyday life [5]. 
In addition, mathemaical story problems are mathemaical story problems in the form of narratives related to everyday life that can be solved using mathematical sentences [6]. So it can be concluded that mathemaical story problems are narrative questions that can be solved using mathematical sentences related to everyday life. Solving mathemaical story problems requires the ability to understand problems and reasoning [7].

Problems commonly encountered by students are related to story questions [8]. In mathematics there are still many students who have difficulty solving story problems [9]. The difficulty experienced by students in learning mathematics is because students tend to memorize formulas more and do not know the concept [10]. The difficulties experienced by students in solving mathemaical story problems cause students to make mistakes [11]. This happens because students cannot apply concepts in mathematics [12]. In addition, lack of knowledge can also cause students to make mistakes [13]. Lack of students' understanding of the questions can also be the cause of students making mistakes [14].

Analysis is the activity of investigating an event to find out the cause. Mistake or inaccurate action is an error against the right thing or previously agreed upon [15]. In addition, the error is a form of error against a predetermined procedure [16]. Based on this opinion, it can be concluded that an error is an error with the correct thing or procedure. Then, error analysis is an activity of investigating errors in matters or procedures to find out the cause. Identifying mistakes made by students is an important activity, because teachers can reduce mistakes made by students so that student achievement will improve [1]. In addition, by knowing the mistakes made by students, the teacher can find out the extent to which students understand the material that has been taught, especially mathematics [17]. The teacher can also give attention to students who need it [18]. Understanding the location of student mistakes can also illustrate how students' ability to master the material [19].

The reality in the field is that there are still many students who make mistakes in solving story problems, especially in the material on the Two-Variable Linear Equation System. Based on the results of interviews with seventh grade mathematics teachers, SMP Negeri 1 kembaran, based on the results of daily tests of two-variable linear equation system material, seventh grade students still have difficulty working on mathemaical story problems, including difficulties in making mathematical models and difficulties in arithmetic operations. This makes students make mistakes in solving story problems. The number of mistakes made by students can show the abilities that students have it [20]. In this study, the Watson criteria were used to determine the location of student errors in each step of the completion. There are 8 Watson's criteria, namely inaccurate data (innappropriate data), it is said to have made an error on this criterion if the student is unable to determine the required information. Inappropriate procedure is said to have made a mistake on this criterion if students cannot determine the method of completion to be used.

Data is missing (ommited data), it is said to have made an error on this criterion if in completion, students do not fully use the data provided in the questions. An omitted conclusion, it is said to have made a mistake on this criterion if the student is unable to write a conclusion or can write a conclusion but the result is wrong due to an error in the calculation. Response level conflict is said to have made a mistake on this criterion if a student experiences a calculation error in solving a mathematical model. Undirected manipulation is said to have made a mistake in this criterion if during the completion process, students have missed a settlement step. Skills hierarchy problem is said to make mistakes on this criterion if students cannot make mathematical models or students do not provide variables in the mathematical model created. In addition, it is said to have made an error on this criterion if students cannot answer the questions given. Based on the background above, the researcher limits and focuses the 
discussion in this study. The research focus is on how to describe student errors in solving mathemaical story problems based on Watson's criteria.

\section{Method}

This type of research is a qualitative descriptive study. This research was conducted at SMP Negeri 1 Kembaran with research subjects 7th grade. The purpose of this research is to describe how the students' mistakes in solving mathemaical story problems based on Watson's criteria. The research subjects were categorized into 3 categories, namely high, medium, and low. From each category, 3 students were taken to be research respondents. Data were collected by means of a written test and strengthened by interviews. The data analysis technique used the Miles and Huberman Model in the form of data reduction, data presentation, and conclusion drawing. The data validation test used technical triangulation by comparing the results of the written test and interviews.

\section{Result and Discussion}

\subsection{Students with High Learning Achievement}

Based on the research that has been done, students with high learning achievement do not make mistakes on the incorrect data criteria. This can be seen when students can determine the information needed on the questions. In addition, at the time of the interview they can also explain what was written. In the criteria of the skill hierarchy problem, students with high learning achievement also did not make mistakes. It is proven when they are able to make mathematical models based on the information that has been obtained in the questions. Likewise, when interviewing, they can explain the process of making a mathematical model. On the incorrect procedure criteria, students did not make mistakes. Seen when they can determine the solution method to solve the mathematical model that has been made. They also know about the method chosen. It was proven when they interviewed that they knew briefly the definition of the method they had chosen and applied that method in solving mathematical models. On the response level conflict criteria, students with high learning achievement made mistakes. This can be seen when they can solve the mathematical models that have been created using the chosen method, but in the process of solving they make mistakes in the calculations. During the interview, they said that when they did their calculations they were not accurate enough that they made mistakes. This shows that students have made negligence which resulted in making mistakes.

In the missing conclusion criteria, students also make mistakes. Seen when students can write conclusions, but make mistakes in the completion process. When the interview can also mention the conclusions that have been made, but students make mistakes on the previous criteria, namely making mistakes when doing calculations so that students make mistakes on this criterion. In addition, students also made mistakes on the missing data criteria. This can be seen when in solving students do not fully use the information on the questions. This happens because students do not understand the questions and make negligence such as not being careful and forgetting to use the information on the questions. In the indirect manipulation criteria, students also made mistakes. It is seen when students miss or fail to write down the steps to solve it. When the interview also said that they thought they would finish quickly in solving 
existing problems, so that students did not write down the steps for solving them. In addition, students also experience a lack of understanding of the meaning of the problem so that they cannot write down the steps to solve it. On the error criteria other than the seven categories, students with high learning achievement did not make mistakes. This can be seen when students can complete the questions given.

\subsection{Students with Medium Learning Achievement}

On the data criteria are not accurate, students' learning achievement is not making mistakes. This can be seen when students can determine the required information appropriately. Likewise, during the interview, students were able to explain the meaning of what they wrote. In the criteria of the skill hierarchy problem, students' learning achievement is making mistakes. It is seen when students can make mathematical models but are incomplete in writing down the variables. In addition, other errors can also be seen when students cannot make mathematical models correctly. When interviewing students said they were not thorough so they made mistakes not writing variables in the mathematical model that had been made and said they did not understand the problem so they could not make a mathematical model correctly. On the incorrect procedure criteria, students did not make mistakes. Seen when students can determine the method of completion to solve the mathematical model that has been made. During the interview, students can also briefly explain the definition of the method chosen and apply it to the process of solving a mathematical model. At the response level conflict criteria, students made mistakes. This can be seen when students make mistakes in calculations. Students said they were not thorough so they made mistakes. In the missing conclusion criteria, students also make mistakes. It is seen when students can write conclusions but make mistakes on the previous criteria, namely making mistakes in calculations.

In the missing data criteria, students' learning achievement is making mistakes on this criterion. This can be seen when in solving students cannot fully use the information in the questions. Occurs because students do not understand the meaning of the questions. In the indirect manipulation criteria, students also made mistakes. It appears that when in progress you cannot write down the steps for completion. Occurs because students do not understand the meaning of the questions. On the error criteria other than the seven categories, students did not make mistakes on this criterion. It is seen when students can answer the questions that have been given.

\subsection{Students with Low Learning Achievement}

On the incorrect data criteria, students with low learning achievement made mistakes on this criterion. This can be seen when students are unable to determine the required information appropriately. Likewise, during the interview, students only mentioned information according to what was written and said they did not understand the questions so they made mistakes. In the skill hierarchy problem criteria, students also make mistakes. Seen when students cannot create mathematical models. The interview also failed to explain the process of making a mathematical model properly. This happens because students do not understand the material. On the incorrect procedure criteria, students make mistakes on this criterion. This can be seen when students cannot determine the method of completion and it occurs because students do not understand the material. On the response level conflict criteria, students with low learning achievement also made mistakes. It is seen when students cannot write down the completion process of the mathematical model. This happens because students make mistakes on the previous criterion, which is not being able to make a mathematical model. 
In the missing conclusion criteria, students make mistakes. Seen when students cannot make the desired conclusions. It occurs because students make mistakes in the previous criteria, namely they cannot complete the mathematical model. In the missing data criteria, students made mistakes when in solving the students could not fully use the information in the questions. Occurs because students do not understand the questions. In the indirect manipulation criteria, students with low learning achievement also made mistakes. This can be seen when students in progress cannot show completion steps. Occurs because students do not understand the questions. When the interview was also unable to explain the steps to solve it. On the error criteria other than the seven categories, students did not make mistakes. It is seen when students can answer some of the questions that have been given. Even though the answers written by students were not quite right.

\section{Conclusion}

Based on the results of the research that has been done, it can be concluded that high learning achievement students made mistakes on the response level conflict criteria, missing conclusions, missing data, and indirect manipulation. The mistakes made by students with moderate learning achievement were errors in the skill hierarchy problem criteria, response level conflicts, missing conclusions, missing data, and indirect manipulation. Low learning achievement students make all errors except those other than the seven categories. Errors that were made occurred in inappropriate data criteria, skill hierarchy problems, inappropriate procedures, response level conflicts, missing conclusions, missing data, and indirect manipulation.

\section{References}

[1] Mingke dan Emybel. 2019. Difficulties Encountered In Mathematical Word Problem Solving Of The Grade Six Learners. International Journal of Scientific and Research Publications (IJSRP), 9(6).

[2] Ozsoy, Gokhan, dkk. 2015. Evaluation of Students' Mathematical Problem Solving Skills in Relation to Their Reading Levels. International Electronic Journal of Elementary Education, 8(1), 113-132.

[3] Herdolt, Roelien dan Ingrid. 2014. An error analysis in the early grades mathematics - A learning opportunity? South African Journal of Childhood Education, 4(1): 42-60.

[4] Seivi, dkk. 2012. Recognition of Students' Difficulties in Solving Mathematical Word Problems from the Viewpoint of Teachers. Journal of Basic and Applied Scientific Research.

[5] Salemeh, Zeina dan Mattew. J. Etchells. 2016. A Case Study: Sources of Difficulties in Solving Word Problems in an International Private School. USA Electronic International Journal of Education, Arts, and Science

[6] Rahmania, L., \& Ana, R. (2016). Analisis kesalahan siswa dalam menyelesaikan soal cerita persamaan linier satu variabel. JMPM: Jurnal Matematika dan Pendidikan Matematika, 1(2), 165174.

[7] Huang, Danqing, dkk. 2018. Neural Math Word Problem Solver with Reinforcement Learning. International Conference on Computational Linguistics.

[8] Wulandari. 2015. Hasil Analisis Kesalahan dalam Menyelesaikan Soal Sistem Persamaan Linear Pesrta Didik SMK Antartika 1 Sidoarjo. Jurnal Pendidikan Matematika STIKIP PGRI Sidoarjo, 2(1).

[9] Pearce, Daniel. L, dkk. 2013. What Teachers Say About Student Difficulties Solving Mathematical Word Problems in Grades 2-5. International Electronic Journal of Mathematics Education, 8(1).

[10] Asrodin. 2018. Difficulty Analysis of the Ninth Grade Students of SMP 2 Pundong in Solving the Conguency Topic in National Examination. The International Conference on Mathematical Analysis. 
[11] Haryanti, dkk. 2018. Analysis of Students' Error in Solving Mathematical Word Problems in Geometry. International Conference on Mathematics and Science Education.

[12] Isleyen, Tevfik dan Emel, Mercan. 2013. Examining the Difficulties Experienced By $8^{\text {th }}$ Grade Students on the Subject Of Square Root Numbers. Journal of Theory and Practice in Education, 9(4): 529-543.

[13] Batanero, C, dkk. 1994. Errors And Difficulties In Understanding Elementary Statistical Concepts. International Journal of Mathematical Education.

[14] Heater, Mary Jane, dkk. 2012. Solving Word Problems: As Easy as PIES! Journal of Science Education for Students with Disabilities, 16(1).

[15] Wijaya dan Masriyah. (2013). Analisis Kesalahan Siswa Dalam Menyelesaikan Soal Cerita Materi Sistem Persamaan Linear Dua Variabel. Surabaya: UNESA.

[16] Ningsih, N., Sri, H., \& Fayeldi, T. (2019). Analisis Kesalahan Siswa dalam Menyelesaikan Soal Lingkaran Berdasarkan Kategori Watson. UNION: Jurnal Ilmiah Pendidikan Matematika, 7(2), 187200.

[17] Kingsdorf, Sheri dan Jennifer Krawec. 2014. Error Analysis of Mathematical Word Problem Solving Across Students with and without Learning Disabilities. Learning Disabilities Research \& Practice, 29(2), 66-74.

[18] Lai, Cheng-Fei. 2012. Error Analysis in Mathematics. Behavioral Research and Teaching.

[19] Bouck, Emily. C., dkk. 2016. Understanding Problem-Solving Errors by Students With Learning Disabilities in Standards-Based and Traditional Curricula. Learning Disabilities: A Multidisciplinary Journal, 21(1).

[20] Marlina, L. (2013). Penerapan Langkah Polya dalam Menyelesaikan Soal Cerita Keliling dan Luas Persegi Panjang. Jurnal Elektronik Pendidikan Matematika Tadulako, 1(1): 43-42. 